\title{
A global analysis of the impact of drought on net primary productivity
}

\author{
T. Chen ${ }^{1,2}$, G. R. van der Werf ${ }^{2}$, R. A. M. de Jeu' ${ }^{2}$, G. Wang ${ }^{2}$, and A. J. Dolman ${ }^{2}$ \\ ${ }^{1}$ School of Atmospheric Sciences, Nanjing University, Nanjing, China \\ ${ }^{2}$ Department of Earth and Life Sciences, Earth and Climate cluster, VU University Amsterdam, the Netherlands
}

Correspondence to: A. J. Dolman (han.dolman@vu.nl)

Received: 5 February 2013 - Published in Hydrol. Earth Syst. Sci. Discuss.: 28 February 2013

Revised: 21 August 2013 - Accepted: 21 August 2013 - Published: 11 October 2013

\begin{abstract}
We investigated the impact of drought on interannual variability of net primary productivity (NPP) from 1997 to 2009, using the standardized precipitation evapotranspiration index (SPEI) drought index and satellite-derived vegetation greenness converted to NPP. SPEI is positive for wet conditions and negative for dry conditions. We found that SPEI and NPP were coupled and showed in-phase behaviour on a global scale. We then used the Köppen climate classification to study the SPEI-NPP relations regionally and found that while NPP and SPEI were positively related (high SPEI, high NPP) in arid and in seasonal dry regions, the opposite occurs in most boreal regions (high SPEI, low NPP). High intensity drought events, such as the 2003 drought in Europe were picked up by our analysis. Our findings suggest that the strong positive relation between global average moisture availability and NPP consists of a composite of the positive relation across dry regions and the coherent NPP decline during and after intensive drought events in humid regions. Importantly, we also found that there are many areas on the globe that show no strong correlation between drought and NPP.
\end{abstract}

\section{Introduction}

Terrestrial ecosystems constitute a substantial $\mathrm{CO}_{2}$ sink, currently of the order of a quarter of emissions from fossil fuels and deforestation (Le Quéré et al., 2009). They exhibit considerable interannual variability, which is to a large extent reflected in the variability of the mean global atmospheric $\mathrm{CO}_{2}$ growth rate (Knorr et al., 2007; Le Quéré et al., 2009; Zhao and Running, 2010). Zhao and Running (2010) suggested a strong correlation between the occurrence of global drought and net primary production (NPP) using the Moderate Resolution Imaging Spectroradiometer (MODIS) NPP algorithm and the Palmer Drought Severity Index (PDSI) as a proxy for soil moisture.

Extreme droughts can impact the terrestrial productivity in a significant way and reduce the sink strength at (sub) continental scale (Ciais et al., 2005; Reichstein et al., 2007a; van der Molen et al., 2011). Several recent droughts, such as those in Australia (2002-2009), Europe (2003), and Amazonia $(2005,2010)$ have had a clear detectable impact on plant productivity (Gobron et al., 2010; Zhao and Running, 2010). Since the occurrence and severity of droughts is likely to increase in the near future as a result of global warming (Dai, 2012, but see also Sheffield et al., 2012), there is a clear need to understand whether the global average results found by Zhao and Running (2010) also apply at smaller spatial scales, and perhaps arguably more important, whether at the level and scale of biomes and climate zones different relationships occur.

Droughts have traditionally been described based on their intensity, duration and spatial extent, or a mixture of this. Precipitation anomalies are often used as a proxy because precipitation is the main water source to the soils. However, the local water balance also depends on evaporation, soil moisture storage, and runoff. Compared with precipitation, drought indices have the advantage that they quantitatively describe both the character of drought events and longterm variations in the mean dry and wet conditions. Furthermore, drought indices have significant advantages over precipitation in analytical applications, as they address the potential impacts much more explicitly, for instance by taking 
into account the duration and cumulative severity. However, Sheffield et al. (2012) also point out that care has to be exercised when extrapolating drought indices that are not based on a full physical description of the relevant processes. While recently remotely sensed soil moisture data have become available for $30 \mathrm{yr}$ (Dorigo et al., 2012; Liu et al., 2012), these data unfortunately suffer sometimes from gaps in the time series and refer in principle only to the first few, variable centimetres of the soil, making their global application in drought studies not yet straightforward.

The previously mentioned drought-vegetation studies generally suggest that at the global scale relationships exist that hide the underlying composite of several regional responses at smaller spatial scales. Importantly then, not only meteorological variability plays a role, but also the general sensitivity or adaptation of the vegetation to drought stresses. Savannah vegetation for instance is likely to be more adapted to periodic drought than a temperate forest that experiences a drought only once in a few years. This calls for the inclusion of biome or vegetation information in the drought-carbon impact analysis. We use here a combination of the Köppen climate classification together with a CASA (CarnegieAmes-Stanford Approach; Potter et al., 1993; van der Werf et al., 2010) derived NPP and the standardized precipitation evapotranspiration index (SPEI; Vicente-Serrano et al., 2010) drought index to investigate this variability. By doing so, we aim to improve the understanding of the relation of drought with vegetation and also detect whether our hypothesis of regionally varying responses is correct.

By using the SPEI index, we believe to have made the appropriate choice to study drought in a more meaningful way than with for instance the PDSI, or other static drought indices. As demonstrated by Heim (2002) and see also the comment on the Discussion paper by Vicente Serrano (2013), over 10 different drought indices have been developed during the twentieth century, of which SPI (standardized precipitation index; McKee et al., 1993) and PDSI are the most widely used (Ji and Peters, 2003; Lotsch et al., 2003; Rhee et al., 2010). PDSI is more physical based but SPI is easy to calculate and has different timescales. This timescale characteristic of SPI is very important to represent different kinds of droughts (McKee et al., 1993). The World Meteorological Organization (WMO) has recommended SPI as the standard drought index. Recently, the SPEI was generated, which relies on a similar algorithm as SPI but including temperature to calculate potential evapotranspiration. Therefore, SPEI combines the advantages of SPI (different timescales) and PDSI (both precipitation and temperature play a role), and is considered to provide a more meaningful parameter to detect the impact of drought on vegetation (Vicente-Serrano et al., 2013) as a consequence. However, following Sheffield et al. (2012) who showed the importance of using a physically based estimate of evaporation in calculating droughts, we use here the SPEI calculated from Penman-Monteith derived estimates of evaporation. This is also an improvement over our earlier analysis.

The objective of this study is thus to investigate how anomalous moisture conditions, as estimated by the SPEI, are related to annual changes in NPP on multiple time and space scales across the globe. We choose NPP as an indicator of carbon sensitivity, so as not having to separate several ecosystem level responses of heterotrophic respiration $(R)$ versus gross primary production (GPP). We appreciate that respiration is also sensitive to drought and soil moisture, but this field is only just evolving and we did not wish to further complicate matters. We also note that these components are usually calculated in models from NPP; therefore, NPP tends to be more useful for our study than either $R$ or NEE and more directly related to ecosystem carbon use than GPP. We use the CASA biogeochemical model (Potter et al., 1993; van der Werf et al., 2010) to estimate NPP. We specifically aimed to provide more spatial detail than Zhao and Running (2010), as it is to be expected that soil moisture-NPP relations are strongest in arid areas and those with a pronounced dry season. In contrast, in cold and humid regions we do not expect a clear relation. We suspect that the global relations as found by Zhao and Running (2010) may hide this regional detail that could be important for the future behaviour of the carbon cycle. Note that it is also important to identify those regions where no clear drought NPP relation exist, as this indicates robustness of the carbon cycle to changes in precipitation and soil moisture in these regions.

\section{Methods}

We used the CASA biogeochemical model (Potter et al., 1993; van der Werf et al., 2010) on a $0.5^{\circ}$ grid with a monthly time step. NPP was calculated by the light use efficiency approach multiplying absorbed photosynthetically active radiation (PAR) and a light use efficiency coefficient, $\varepsilon$ (Monteith, 1972, 1977):

$\mathrm{NPP}=\mathrm{PAR} \times \mathrm{fPAR} \times \varepsilon^{*} \times f(\varepsilon)$,

where PPAR is the fraction of PAR absorbed by vegetation, $f(\varepsilon)$ accounts for environmental stress governed by temperature and moisture. CASA employs a sub-model to calculate the soil moisture balance. The model keeps a running water balance where the main impact of soil moisture on GPP is given by a water stress factor $\left(W_{\varepsilon}\right)$ which is calculated as $W_{\varepsilon}=0.5+0.5 \cdot P / \mathrm{PET}$, where PET is the potential evapotranspiration and $P$ is the precipitation. This equation, though arguably simple, contains the primary responses of NPP to soil moisture. The factor 0.5 is chosen to incorporate the effect that in the fPAR data used in CASA, a soil moisture effect would also be visible, because fPAR will decrease when the wilting occurs due to the shortage of soil moisture. More details of $f(\varepsilon)$ can be found in Potter et al. (1993). $\varepsilon^{*}$ was set to $0.5 \mathrm{~g} \mathrm{CMJ}^{-1}$ PAR globally to match global NPP 
values of $60 \mathrm{Pg} \mathrm{C} \mathrm{yr}^{-1}$ (Beer et al., 2010). International Satellite Cloud Climatology Project (ISCCP) solar radiation data (Zhang et al., 2004) were used here to generate PAR. fPAR data were calculated based on normalized difference vegetation index (NDVI) from the Advanced Very High Resolution Radiometer (AVHRR, Tucker et al., 2005) and Moderate Resolution Imaging Spectroradiometer (MODIS) products (Myneni et al., 2002). Precipitation from the Global Precipitation Climatology Project (GPCP) version 1.1 (Huffman et al., 2001) and temperature of the Goddard Institute for Space Sciences (GISS) surface temperature analysis (Hansen et al., 1999) were employed to quantify environmental drivers. Further details are provided by van der Werf et al. (2010).

We use the latest SPEI v2.2 data (available from https: //digital.csic.es/handle/10261/72264) in this study. SPEI v2.2 involves CRU TS3.2 monthly gridded temperature and PET. The FAO (Food and Agricultural Organization) grass reference method, a variant of the Penman-Monteith method, is using in the PET calculation. More details of PET calculation and application limitations across vegetation types can be found in Ekström et al. (2007) and Allen et al. (1994). The difference between precipitation (PPT) and PET, as a simplified water balance, was calculated as

$D=$ PPT - PET.

$D$ was calculated for each grid cell and month following

$D_{j}^{k}=\sum_{i=0}^{k-1}\left(\operatorname{PPT}_{j-i}-\operatorname{PET}_{j-i}\right), j \geq k$,

where $k$ is timescale, in months. A three-parameter loglogistic distribution was used to model these $D$ series, with the function given by

$F(x)=\left[1+\left(\frac{\alpha}{x-\gamma}\right)^{\beta}\right]^{-1}$,

where $\alpha, \beta$, and $\gamma$ indicate scale, shape and origin parameters, respectively. This function was chosen as the best distribution function by $L$ moment ratio diagrams to fit $D$ series (Vicente-Serrano et al., 2010). Finally, SPEI data were calculated by standardizing $F(x)$. More details are provided in Vicente-Serrano et al. (2010).

The response of hydrological systems to moisture deficits varies over timescales. On short timescales surface runoff and soil moisture are of concern while at longer timescales stream flow and ground water levels are important (Changnon and Easterling, 1989). Mathematically, SPEI can be calculated on any timescale, but the scales typically used are 1-, 3-, 6-, 12-, and 24-months. In all, 3-, 5- and 6month SPI have been used to indicate soil moisture conditions (Hirschi et al., 2011; Ji and Peters, 2003; Lotsch et al., 2003) and 2-3 months SPI may indicate agricultural drought best (Mishra and Desai, 2005). We focused our analysis on 1-, 3-, and 6-month SPEI values to capture variability in soil moisture conditions from surface to deeper rooting depths.
Table 1. List of regions referred to this paper. Abbreviations consist of the first two letters of Köppen climate classification (indicating climate) and two letters to identify the continent or region. For example, AFAF is first group (A, equatorial) humid (F) in Africa (AF).

\begin{tabular}{|c|c|c|}
\hline Abbreviation & $\begin{array}{l}\text { Köppen climate } \\
\text { classification }\end{array}$ & Continent or region \\
\hline AFAF & $\begin{array}{l}\text { equatorial climates, humid } \\
\text { and monsoon (Af, Am) }\end{array}$ & Africa \\
\hline AFEA & $\begin{array}{l}\text { equatorial climates, humid } \\
\text { and monsoon (Af, Am) }\end{array}$ & $\begin{array}{l}\text { Eurasia and north } \\
\text { Oceania }\end{array}$ \\
\hline AFSA & $\begin{array}{l}\text { equatorial climates, humid } \\
\text { and monsoon (Af, Am) }\end{array}$ & $\begin{array}{l}\text { Central and South } \\
\text { America }\end{array}$ \\
\hline AWAF & $\begin{array}{l}\text { equatorial climates with } \\
\text { winter dry (Aw) }\end{array}$ & Africa \\
\hline AWEA & $\begin{array}{l}\text { equatorial climates with } \\
\text { winter dry }(\mathrm{Aw})\end{array}$ & $\begin{array}{l}\text { Eurasia and north } \\
\text { Oceania }\end{array}$ \\
\hline AWSA & $\begin{array}{l}\text { equatorial climates with } \\
\text { winter dry (Aw) }\end{array}$ & $\begin{array}{l}\text { Central and South } \\
\text { America }\end{array}$ \\
\hline BBAF & $\begin{array}{l}\text { arid climates (BWk, BWh, } \\
\text { BSk, BSh) }\end{array}$ & Africa \\
\hline BBEA & $\begin{array}{l}\text { arid climates (BWk, BWh, } \\
\text { BSk, BSh) }\end{array}$ & Eurasia \\
\hline BBNA & $\begin{array}{l}\text { arid climates (BWk, BWh, } \\
\text { BSk, BSh) }\end{array}$ & North America \\
\hline $\mathrm{BBOC}$ & $\begin{array}{l}\text { arid climates (BWk, BWh, } \\
\text { BSk, BSh) }\end{array}$ & Oceania \\
\hline BBSA & $\begin{array}{l}\text { arid climates (BWk, BWh, } \\
\text { BSk, BSh) }\end{array}$ & $\begin{array}{l}\text { Central and South } \\
\text { America }\end{array}$ \\
\hline CFAS & $\begin{array}{l}\text { temperate climates, humid } \\
(\mathrm{Cfa}, \mathrm{Cfb}, \mathrm{Cfc})\end{array}$ & Asian \\
\hline CFEU & $\begin{array}{l}\text { temperate climates, humid } \\
(\mathrm{Cfa}, \mathrm{Cfb}, \mathrm{Cfc})\end{array}$ & Europe \\
\hline CFNA & $\begin{array}{l}\text { temperate climates, humid } \\
(\mathrm{Cfa}, \mathrm{Cfb}, \mathrm{Cfc})\end{array}$ & North America \\
\hline CFOC & $\begin{array}{l}\text { temperate climates, humid } \\
(\mathrm{Cfa}, \mathrm{Cfb}, \mathrm{Cfc})\end{array}$ & Oceania \\
\hline CFSA & $\begin{array}{l}\text { temperate climates, humid } \\
(\mathrm{Cfa}, \mathrm{Cfb}, \mathrm{Cfc})\end{array}$ & $\begin{array}{l}\text { Central and South } \\
\text { America }\end{array}$ \\
\hline CSEA & $\begin{array}{l}\text { temperate climates with } \\
\text { summer dry (Csa, Csb, } \\
\text { Csc) }\end{array}$ & Mediterranean Sea \\
\hline CWAF & $\begin{array}{l}\text { temperate climates with } \\
\text { winter dry (Cwa, Cwb, } \\
\text { Cwc) }\end{array}$ & Africa \\
\hline CWEA & $\begin{array}{l}\text { temperate climates with } \\
\text { winter dry (Cwa, Cwb, } \\
\text { Cwc) }\end{array}$ & Eurasia \\
\hline DFEA & $\begin{array}{l}\text { cold climates, humid (Dfa, } \\
\text { Dfb, Dfc, Dfd) }\end{array}$ & Eurasia \\
\hline DFNA & $\begin{array}{l}\text { cold climates, humid (Dfa, } \\
\text { Dfb, Dfc, Dfd) }\end{array}$ & North America \\
\hline DWEA & $\begin{array}{l}\text { cold climates with win- } \\
\text { ter dry (Dwa, Dwb, Dwc, } \\
\text { Dwd) }\end{array}$ & Eurasia \\
\hline ETAT & polar tundra $(\mathrm{ET})$ & Arctic \\
\hline ETQT & polar tundra (ET) & Eurasia \\
\hline
\end{tabular}

Annual SPEI data were calculated from original monthly SPEI using all months in the year. Pearson correlation coefficients were calculated for the annual NPP vs. 1-, 3-, and 
6-month SPEI values. We removed the linear trends from annual NPP and SPEI time series during correlation calculation. To aid the interpretation of our analyses, we divided the global land surface into 24 climate regions across continents based on both geographical location and the Köppen climate classification (Kottek et al., 2006, Fig. 1, Table 1). We did not combine all regions with an identical climate type across continents to maintain variability due to region-specific meteorological conditions. In the Köppen climate classification, first letters are used to indicate the main climate groups, i.e. group A concerns equatorial climate; group B arid climates; group C temperate climates; group D continental cold climates and group $\mathrm{E}$ consists of polar climates. Within the Köppen climate classification, we separated arid, humid and seasonal (summer or winter) dry types besides the five main groups. Only those classes that occupy at least $1 \%$ of the global land surface were included in our study with the exception of temperate humid Oceania (CFOC), which is the second largest climate type there.

\section{Results}

Global CASA calculated NPP showed a decreasing trend for the period of 1997-2009, similar to that found by Zhao and Running (2010), but also displayed substantial interannual variation (Fig. 2). The global SPEI series exhibited almost the same trend, and showed a similar pattern that appeared well in phase with NPP. On a global scale, for example, dry conditions happened in 2002-2003, 2005 and 2009 with lower NPP and SPEI values. 2004 was a wet year and NPP and SPEI were above average compared to other years. SPEI values changed somewhat when calculated over different timescales, with the maximum range between 1 and 6 month SPEI occurring in 2006. The annual variance of SPEI was increasing from 1 month to 6 months timescales as shown in Fig. 2. However, the interannual pattern was robust and the calculated correlation coefficients between NPP and SPEI were $0.55(p<0.1), 0.51(p<0.1)$ and 0.43 for $1-, 3$ and 6-month SPEI, respectively (Table 2). There was a slight declining trend in both SPEI and CASA derived NPP, similar to Zhao and Running (2010), despite adding the years 1997-1999 to the analysis.

We now proceed to investigate at finer spatial resolution the observed relationships by analyzing the correlation between NPP and SPEI at grid cell level. Since the spatial patterns corresponding to 1-, 3-, 6-month SPEI are very similar, we only show the 3-month SPEI-CASA NPP relation (Fig. 3). Figure 3 illustrates that at 0.5-degree spatial resolution significant positive relations between SPEI and NPP are present. These occur largely at the mid-latitudes of both hemispheres. Significant negative relations were mainly observed in the boreal region. NPP in the Southern Hemisphere appeared to be more sensitive to SPEI indicated by high correlation values.

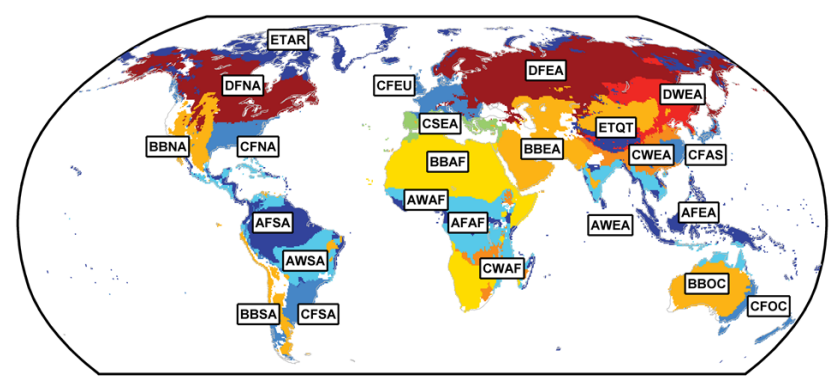

Fig. 1. Map of 24 regions used in our study. Abbreviations are explained in Table 1.

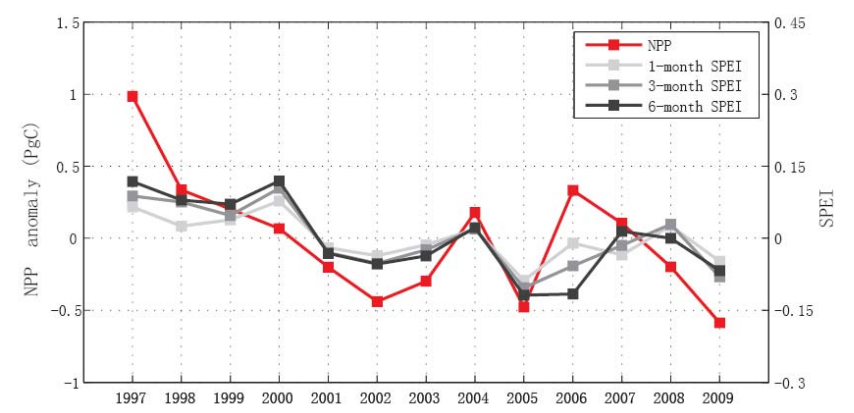

Fig. 2. Interannual variation in global NPP and SPEI anomalies during 1997-2009. Both NPP and SPEI are area-weighted.

To bring in the vegetation component more explicitly, we now analyze the relationship between SPEI and NPP in more detail using the Köppen climate classification across continents. Compared with the global results of NPP and SPEI, the correlation coefficients in several regions exhibit much more change with different SPEI timescales, such as the range of 0.57 in cold humid Eurasia (DFEA) (Table 2). This implies that the impact of drought on the ecosystems in this area varies with different SPEI timescales, and that NPP is sensitive only to droughts specified by a narrow range of timescales. Significant values occurred at 1 to 3 -month scales and the absolute values are much higher than using the 6month scale, which we suspect is caused by the very short growing period during summer in this region. In contrast, in several other regions, arid South America (BBSA) for example, we observed little change in response when using different timescales (Table 2) suggesting that in these cases the vegetation is less sensitive to the precise timescale of the drought.

Complementing Table 2, Fig. 4 shows time series of annual 3-month SPEI and NPP anomalies between 1997 and 2009 for these 24 regions. As expected, NPP and SPEI have similar temporal patterns in arid regions (climate group B, Fig. 4g-k), showing significant positive correlation coefficients for the arid regions of North America (BBNA), Eurasian (BBEA), Africa (BBAF) Australia (BBOC) and Central and South America (BBSA). In contrast, NPP and 
Table 2. Correlation coefficients $(R)$ between annual anomalies of NPP and SPEI for the global and for the 24 regions explained in Table 1. Significant values $(p<0.1)$ are indicated by $*$.

\begin{tabular}{rrrrrrrrrr}
\hline SPEI & global & AFAF & AFEA & AFSA & AWAF & AWEA & AWSA & BBAF & BBEA \\
\hline 1 & $0.55^{*}$ & 0.20 & -0.31 & 0.36 & $0.91^{*}$ & 0.30 & $0.79^{*}$ & $0.55^{*}$ & 0.29 \\
2 & $0.51^{*}$ & 0.34 & -0.22 & 0.30 & $0.87^{*}$ & $0.56^{*}$ & $0.85^{*}$ & 0.40 & $0.60^{*}$ \\
3 & 0.43 & 0.44 & 0.12 & 0.34 & $0.66^{*}$ & $0.67^{*}$ & $0.87^{*}$ & 0.37 & $0.72^{*}$ \\
\hline & BBNA & BBOC & BBSA & CFAS & CFEU & CFNA & CFOC & CFSA & CSEA \\
\hline 1 & $0.81^{*}$ & $0.74^{*}$ & 0.45 & -0.11 & 0.44 & -0.26 & $0.65^{*}$ & -0.39 & 0.30 \\
2 & $0.86^{*}$ & $0.84^{*}$ & $0.50^{*}$ & -0.31 & 0.25 & -0.16 & $0.62^{*}$ & -0.26 & 0.41 \\
3 & $0.93^{*}$ & $0.87^{*}$ & $0.48^{*}$ & -0.34 & 0.39 & -0.01 & $0.52^{*}$ & -0.12 & $0.58^{*}$ \\
\hline & CWAF & CWEA & DFEA & DFNA & DWEA & ETAR & ETQT & & \\
\hline 1 & $0.55^{*}$ & 0.29 & $-0.68^{*}$ & -0.46 & $-0.63^{*}$ & -0.20 & -0.22 & & \\
2 & $0.57^{*}$ & 0.14 & $-0.53^{*}$ & $-0.48^{*}$ & $-0.63^{*}$ & -0.26 & -0.21 & & \\
3 & 0.45 & 0.21 & -0.11 & $-0.54^{*}$ & $-0.56^{*}$ & -0.17 & -0.17 & & \\
\hline
\end{tabular}

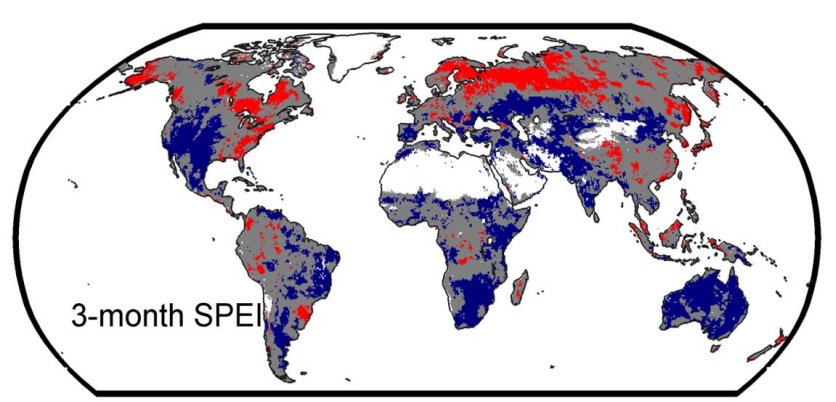

Fig. 3. Spatial distribution of Pearson's correlation coefficients between annual anomalies of NPP and SPEI (3-months). Correlations that are significant $(p<0.1)$ are displayed in blue (positive) and red (negative). Grey areas indicate correlations that are not significant and white areas are not available due to data structure.

SPEI exhibited out of phase correlations during the whole period in the boreal Northern Hemisphere with cold climate (climate group D), i.e. cold-humid North America and North Eurasian (DFNA, DFEA) and cold climates with winter dry North Eurasian (DWEA) as shown in Fig. 4t-v.

Unlike arid and cold regions, other climate zones do not show globally uniform positive or negative patterns. Weak relations are mostly found in temperate humid regions. North America (CFNA), South and Central America (CFSA), Asia (CFAS) and Europe (CFEU) show a mix of both positive and negative correlation coefficients. An exception was Oceania of East Australia and New Zealand (CFOC) where NPP and SPEI had a significant positive relation (Table 2).

During 1997-2002 in temperate humid Europe SPEI was in anti-phase (negatively correlated) to NPP (Fig. 4m). This suggests that during that period no very strong water limitations were experienced and maybe higher temperatures did lead to more carbon uptake (e.g. Goulden et al., 1996). However, NPP exhibited a sharp decline with SPEI in 2003. In
2003 a severe drought hit Europe during summer and autumn, leading to considerable carbon loss across mid- and southern Europe at many ecosystems (Ciais et al., 2005; Reichstein et al., 2007a). Equatorial humid regions show similar behaviour as the temperate humid regions in that they generally have no obvious relation with SPEI (Fig. 4a-c, Table 2). It is worth noting the absence of these relations, as this suggests that at least for the currently available variability in precipitation, these regions are relatively robust in their NPP. We will discuss this issue further in the discussion.

The regions that have seasonally occurring dry periods including summer or winter dry periods are those in middle latitude and equatorial zones. However, as expected, all the winter dry equatorial regions (AWAF, AWEA and AWSA) have significant correlations between NPP and SPEI (Table 2). Further, temperate regions with summer dry regions around the Mediterranean (CSEA) also showed a significant correlation between 6-month SPEI and NPP (Table 2). This suggests that once dry seasons are occurring well within the growing season, annual NPP is also positively correlated to SPEI.

As shown above, the relationships between NPP and SPEI vary with the regions of the Köppen climate classification. Generally, however, different climate zones exist because of the variability of energy and water input with latitude. Therefore, we also show the correlations against latitude and calculated the contribution to global NPP to identify in which areas the sensitivity to global NPP is most pronounced (Fig. 5). Figure 5 clearly shows the tropics as dominant contributor to global NPP, but with generally low sensitivity to drought. Between 20 and $40^{\circ} \mathrm{S}$, and between roughly 20 and $50^{\circ} \mathrm{N}$ we observe strong positive correlations, as indeed in Zhao and Running (2010) but these areas contribute less to global NPP. 

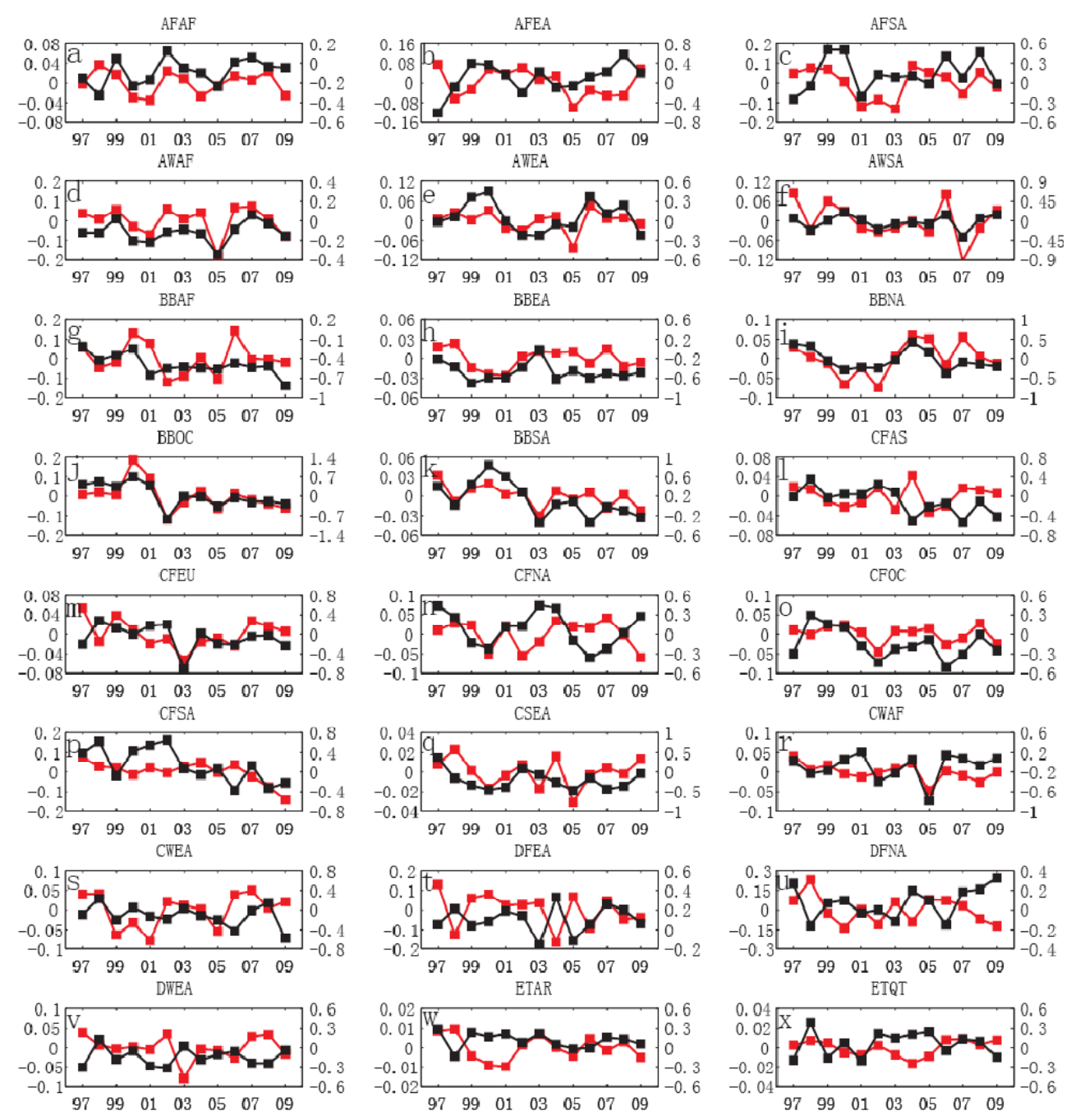

NPP

$\longrightarrow$ 3-month SPEI

Fig. 4. Regional average of SPEI and NPP anomalies for the 24 regions listed in Table 1.

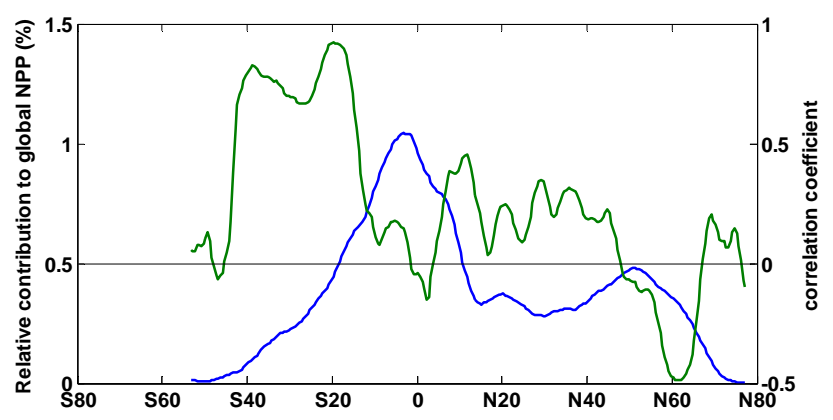

Fig. 5. Correlation coefficients of latitudinal zone averaged NPP and SPEI (green) and NPP contributions as a percentage of global NPP (blue). 5-degree moving averages were applied to all 0.5-degree steps along latitude.

\section{Discussions and conclusions}

The response of NPP to drought is one of the key dynamic processes of the global carbon cycle. We found a statistically significant relation between global NPP and the drought index SPEI, similar to Zhao and Running (2010) who studied this for a shorter time frame. Although a substantial part of the land surface exhibited opposing patterns, this global relation was for a large part driven by the larger areas of the globe where more soil moisture leads to increased NPP. This was especially obvious in the response that was dominated by the landmasses in the Southern Hemisphere similar to the soil moisture driven decline in evaporation (Jung et al., 2010) and most probably related to the variability in rainfall caused by the El Niño-La Niña cycle. Although NPP decreased slightly during this period, we prefer to emphasise here its variation rather than the trend because the variations are generally 
more reliable. Furthermore, our results differ also slightly from the values reported previously due to the use of different models and different time frames. For example, in 2005 the NPP anomaly in the current paper is $-0.5 \mathrm{PgC}$ but Zhao and Running (2010) reported an anomaly of $-1.5 \mathrm{PgC}$ NPP.

Global NPP is one of the prime factors determining the rate of atmospheric $\mathrm{CO}_{2}$ growth rate (Zhao and Running, 2010) and the El Niño/La Niña-Southern Oscillation (ENSO) is known to be correlated strongly to the interannual variability of the growth rate. The mechanism for this is generally attributed to the variation of tropical terrestrial ecosystem NPP driven by variability in precipitation (Zeng et al., 2005) and/or increased fire and deforestation activity during drought years (van der Werf et al., 2004). We have shown how for the tropical landmass with a dry period SPEI shows a clear relation with NPP (Fig. 4d-f), which suggests drought impacts are indeed part of this mechanism. However, negative NPP anomalies at northern mid-latitudes caused by drought events, may also contribute significantly to a lower NPP and the atmospheric $\mathrm{CO}_{2}$ growth during a moderate $\mathrm{El}$ Niño, for example during 2002-2003 (Knorr et al., 2007).

Both regional averages and our grid scale correlation analysis showed spatial variations in the relation between NPP and SPEI. The contrast in response occurred largely between arid regions in the mid-latitudes and the cold humid regions boreal in northern latitudes where NPP and SPEI were correlated positively or negatively, respectively.

Global terrestrial ecosystem growth is mainly controlled by radiation, temperature and water availability (Nemani et al., 2003). The arid regions suffer more strongly from water deficits while in those areas radiation and temperature are generally not important limiting factors. For instance, in the western United States, where long-term aridity changes significantly with a warmer climate (Cook et al., 2004), SPEI and NPP exhibited significant correlations (Fig. 4i). In contrast, in boreal regions, temperature plays a more important role in explaining NPP variability (Reichstein et al., 2007b). It is important to note that apart from the arid regions, most of seasonally dry regions also show positive relations between NPP and SPEI, particularly if the dry season occurs within the growing season, i.e. the winter dry equatorial regions (AWAF, AWEA and AWSA) and temperate summer dry regions around the Mediterranean (CSEA).

Two regional droughts are important to test the robustness of our results and serve as case studies: the 2003 European heat wave and the 2005 Amazon drought. Vegetation growth over most areas of Europe is generally presumed to be limited primarily by temperature and radiation (Nemani et al., 2003). However, we did find strong NPP and SPEI negative anomalies during 2003 (Fig. 4m) that present a substantial change from previous years. This implies that the net effect of temperature, radiation, and water limitation on NPP depends primarily on the intensity of drought. This highlights the sensitivity of the ecosystem carbon cycle in these areas to climate variability, in particular extreme drought and rainfall events. It is however difficult from our analysis to detect a clear threshold that separates the positive from the negative effects of drought on NPP. It is clear that severe droughts, such as those in 2003 in Europe reduce NPP significantly.

In contrast, we are not able to detect an intense NPP decline in Amazon rainforest during 2005 although Phillips et al. (2009) reported substantial tree mortality. Zhao and Running (2010) also found a clear relation between a negative anomaly in soil moisture and a decline in NPP in tropical forests. In our case (not shown here), negative NPP anomalies occur at some regions where a strong decline in biomass is reported by Phillips et al. (2009), but do not overlap fully. We note that whether there was a significant decline in NPP in 2005 in the Amazon is still subject to controversy (Samanta et al., 2011). However, if the CASA model underestimated the Amazon NPP decline in 2005, global SPEI and NPP would show an even stronger in-phase coupled behaviour. Besides these two cases, for the Australian continental drought (2002-2009) we find a very strong relationship between SPEI and NPP.

In this study we aimed to provide more regional and biome detail to the global relations found in Zhao and Running (2010) by analyzing the relation between moisture conditions and NPP at regional to global scales. At a global scale, 1-, 3-, 6-month SPEI and NPP are positively and significantly related, confirming the results of Zhao and Running (2010). We divided the global land surface into different regions based on the Köppen climate classification. SPEI and NPP show significant and positive relations in the arid and seasonally dry in temperate and equatorial zones regions. In contrast, SPEI and NPP in cold regions in the boreal Northern Hemisphere exhibit a negative relation. At grid level, grids with a significant positive relation occurred more often than those with a negative relation. At a global level, consequently, NPP and SPEI are mostly coupled and in phase.

Our study demonstrates that at annual timescale NPP variance is strongly correlated to the variability in dry and wet condition as expressed by the drought index SPEI. Using a drought index appeared an effective way to estimate the impact of drought on NPP. The spatial non-uniform pattern of drought impact on NPP should be taken into account in further analysis and may serve as benchmark for global vegetation models (Sitch et al., 2008). Our results demonstrate that the strong correlation between global NPP and drought found by Zhao and Running (2010) is a composite of the inherent positive relations in global extend dry regions (arid and seasonal dry) and some extreme drought events in humid areas. Further work in comparing the correlation between several drought indices and NPP may be able to elucidate more clearly some of the contrasting results between previous studies (e.g. Zhao and Running, 2010).

From our analysis we cannot unequivocally set a threshold to define the drought impact on ecosystems. However, with global climate change expected to lead to more frequent droughts (Dai, 2012; Sheffield et al., 2012), we can expect 
further large regional declines in NPP to occur. How these are counterbalanced by areas with increases in NPP, or whether they lead to an overall negative trend in NPP, can only be studied by increased monitoring of droughts and NPP, preferably through satellite remote sensing (Dolman and de Jeu, 2010).

Acknowledgements. A. J. Dolman, R. de Jeu and T. Chen acknowledge the support from the European Union Grants FP7-226701 (Project CARBO-EXTREME) and FP7-244240 (Project CLIMAFRICA). T. Chen acknowledges the support of the State Scholarship Fund of China Scholarship Council (CSC). T. Chen acknowledges Xing CHEN's (Nanjing University) supervision and discussions. We appreciate the help from Sergio M. VicenteSerrano with calculating SPEI. We acknowledge the three reviewers and the editor that their comments improve this paper significantly.

Edited by: B. van den Hurk

\section{References}

Allen, R. G., Smith, M., Pereira, L. S., and Perrier, A.: An update for the calculation of reference evapotranspiration, ICID bulletin, 43, 35-92, 1994.

Beer, C., Reichstein, M., Tomelleri, E., Ciais, P., Jung, M., Carvalhais, N., Rodenbeck, C., Arain, M. A., Baldocchi, D., Bonan, G. B., Bondeau, A., Cescatti, A., Lasslop, G., Lindroth, A., Lomas, M., Luyssaert, S., Margolis, H., Oleson, K. W., Roupsard, O., Veenendaal, E., Viovy, N., Williams, C., Woodward, F. I., and Papale, D.: terrestrial gross carbon dioxide uptake: global distribution and covariation with climate, Science, 329, 834-838, doi:10.1126/science.1184984, 2010.

Changnon, S. A. and Easterling, W. E.: Measuring drought impacts - the Illinois case, Water Resour. Bull., 25, 27-42, 1989.

Ciais, P., Reichstein, M., Viovy, N., Granier, A., Ogee, J., Allard, V., Aubinet, M., Buchmann, N., Bernhofer, C., Carrara, A., Chevallier, F., De Noblet, N., Friend, A. D., Friedlingstein, P., Grunwald, T., Heinesch, B., Keronen, P., Knohl, A., Krinner, G., Loustau, D., Manca, G., Matteucci, G., Miglietta, F., Ourcival, J. M., Papale, D., Pilegaard, K., Rambal, S., Seufert, G., Soussana, J. F., Sanz, M. J., Schulze, E. D., Vesala, T., and Valentini, R.: Europe-wide reduction in primary productivity caused by the heat and drought in 2003, Nature, 437, 529-533, doi:10.1038/nature03972, 2005.

Cook, E. R., Woodhouse, C. A., Eakin, C. M., Meko, D. M., and Stahle, D. W.: Long-term aridity changes in the western United States, Science, 306, 1015-1018, doi:10.1126/science.1102586, 2004.

Dai, A.: Increasing drought under global warming in observations and models, Nature Climate Change, 2, 491-496, doi:10.1038/nclimate1633, 2012.

Dolman, A. J. and de Jeu, R. A. M.: Evaporation in focus, Nat. Geosci., 3, 296-296, doi:10.1038/ngeo849, 2010.

Dorigo, W., de Jeu, R., Chung, D., Parinussa, R., Liu, Y., Wagner, W., and Fernandez-Prieto, D.: Evaluating global trends (19882010) in harmonized multi-satellite surface soil moisture, Geophys. Res. Lett., 39, L18405, doi:10.1029/2012g1052988, 2012.
Ekström, M., Jones, P. D., Fowler, H. J., Lenderink, G., Buishand, T. A., and Conway, D.: Regional climate model data used within the SWURVE project - 1: projected changes in seasonal patterns and estimation of PET, Hydrol. Earth Syst. Sci., 11, 1069-1083, doi:10.5194/hess-11-1069-2007, 2007.

Gobron, N., Belward, A., Pinty, B., and Knorr, W.: Monitoring biosphere vegetation 1998-2009, Geophys. Res. Lett., 37, L15402, doi:10.1029/2010GL043870, 2010.

Goulden, M. L., Munger, J. W., Fan, S. M., Daube, B. C., and Wofsy, S. C.: Exchange of carbon dioxide by a deciduous forest: Response to interannual climate variability, Science, 271, 15761578, 1996.

Hansen, J., Ruedy, R., Glascoe, J., and Sato, M.: GISS analysis of surface temperature change, J. Geophys. Res.-Atmos., 104, 30997-31022, doi:10.1029/1999jd900835, 1999.

Heim, R. R.: A review of twentieth-century drought indices used in the United States, B. Am. Meteorol. Soc., 83, 1149-1165, 2002.

Hirschi, M., Seneviratne, S. I., Alexandrov, V., Boberg, F., Boroneant, C., Christensen, O. B., Formayer, H., Orlowsky, B., and Stepanek, P.: Observational evidence for soil-moisture impact on hot extremes in southeastern Europe, Nat. Geosci., 4, 17-21, doi:10.1038/Ngeo1032, 2011.

Huffman, G. J., Adler, R. F., Morrissey, M. M., Bolvin, D. T., Curtis, S., Joyce, R., McGavock, B., and Susskind, J.: Global precipitation at one-degree daily resolution from multisatellite observations, J. Hydrometeorol., 2, 36-50, doi:10.1175/15257541(2001)002<0036:GPAODD>2.0.CO;2, 2001.

Ji, L. and Peters, A. J.: Assessing vegetation response to drought in the northern Great Plains using vegetation and drought indices, Remote Sens. Environ., 87, 85-98, doi:10.1016/S00344257(03)00174-3, 2003.

Jung, M., Reichstein, M., Ciais, P., Seneviratne, S. I., Sheffield, J., Goulden, M. L., Bonan, G., Cescatti, A., Chen, J. Q., de Jeu, R., Dolman, A. J., Eugster, W., Gerten, D., Gianelle, D., Gobron, N., Heinke, J., Kimball, J., Law, B. E., Montagnani, L., Mu, Q. Z., Mueller, B., Oleson, K., Papale, D., Richardson, A. D., Roupsard, O., Running, S., Tomelleri, E., Viovy, N., Weber, U., Williams, C., Wood, E., Zaehle, S., and Zhang, K.: Recent decline in the global land evapotranspiration trend due to limited moisture supply, Nature, 467, 951-954, doi:10.1038/nature09396, 2010.

Knorr, W., Gobron, N., Scholze, M., Kaminski, T., Schnur, R., and Pinty, B.: Impact of terrestrial biosphere carbon exchanges on the anomalous $\mathrm{CO}_{2}$ increase in 2002-2003, Geophys. Res. Lett., 34, L09703, doi:10.1029/2006GL029019, 2007.

Kottek, M., Grieser, J., Beck, C., Rudolf, B., and Rubel, F.: World map of the Koppen-Geiger climate classification updated, Meteorol. Z., 15, 259-263, doi:10.1127/0941-2948/2006/0130, 2006.

Le Quéré, C., Raupach, M. R., Canadell, J. G., Marland, G., Bopp, L., Ciais, P., Conway, T. J., Doney, S. C., Feely, R. A., Foster, P., Friedlingstein, P., Gurney, K., Houghton, R. A., House, J. I., Huntingford, C., Levy, P. E., Lomas, M. R., Majkut, J., Metzl, N., Ometto, J. P., Peters, G. P., Prentice, I. C., Randerson, J. T., Running, S. W., Sarmiento, J. L., Schuster, U., Sitch, S., Takahashi, T., Viovy, N., van der Werf, G. R., and Woodward, F. I.: Trends in the sources and sinks of carbon dioxide, Nat. Geosci., 2, 831-836, doi:10.1038/ngeo689, 2009.

Liu, Y. Y., Dorigo, W. A., Parinussa, R. M., de Jeu, R. A. M., Wagner, W., McCabe, M. F., Evans, J. P., and van Dijk, A. I. J. 
M.: Trend-preserving blending of passive and active microwave soil moisture retrievals, Remote Sens. Environ., 123, 280-297, doi:10.1016/j.rse.2012.03.014, 2012.

Lotsch, A., Friedl, M. A., Anderson, B. T., and Tucker, C. J.: Coupled vegetation-precipitation variability observed from satellite and climate records, Geophys. Res. Lett., 30, 1774, doi:10.1029/2003gl017506, 2003.

McKee, T. B., Doesken, N. J., and Kleist, J.: The relationship of drought frequency and duration to time scales, Eighth Conference on Applied Climatology, American Meteorological Society, 17-23 January, 1993, Anaheim CA, 179-186, 1993.

Mishra, A. K. and Desai, V.: Drought forecasting using stochastic models, Stoch. Env. Res. Risk A, 19, 326-339, doi:10.1007/s00477-005-0238-4, 2005.

Monteith, J. L.: Solar-radiation and productivity in tropical ecosystems, J. Appl. Ecol., 9, 747-766, 1972.

Monteith, J. L.: Climate and efficiency of crop production in Britain, Philos. T. Roy. Soc. B, 281, 277-294, 1977.

Myneni, R. B., Hoffman, S., Knyazikhin, Y., Privette, J. L., Glassy, J., Tian, Y., Wang, Y., Song, X., Zhang, Y., Smith, G. R., Lotsch, A., Friedl, M., Morisette, J. T., Votava, P., Nemani, R. R., and Running, S. W.: Global products of vegetation leaf area and fraction absorbed PAR from year one of MODIS data, Remote Sens. Environ., 83, 214-231, doi:10.1016/S00344257(02)00074-3, 2002.

Nemani, R. R., Keeling, C. D., Hashimoto, H., Jolly, W. M., Piper, S. C., Tucker, C. J., Myneni, R. B., and Running, S. W.: Climate-driven increases in global terrestrial net primary production from 1982 to 1999 , Science, 300, 1560-1563, doi:10.1126/science.1082750, 2003.

Phillips, O. L., Aragao, L. E. O. C., Lewis, S. L., Fisher, J. B., Lloyd, J., Lopez-Gonzalez, G., Malhi, Y., Monteagudo, A., Peacock, J., Quesada, C. A., van der Heijden, G., Almeida, S., Amaral, I., Arroyo, L., Aymard, G., Baker, T. R., Banki, O., Blanc, L., Bonal, D., Brando, P., Chave, J., de Oliveira, A. C. A., Cardozo, N. D., Czimczik, C. I., Feldpausch, T. R., Freitas, M. A., Gloor, E., Higuchi, N., Jimenez, E., Lloyd, G., Meir, P., Mendoza, C., Morel, A., Neill, D. A., Nepstad, D., Patino, S., Penuela, M. C., Prieto, A., Ramirez, F., Schwarz, M., Silva, J., Silveira, M., Thomas, A. S., ter Steege, H., Stropp, J., Vasquez, R., Zelazowski, P., Davila, E. A., Andelman, S., Andrade, A., Chao, K. J., Erwin, T., Di Fiore, A., Honorio, E., Keeling, H., Killeen, T. J., Laurance, W. F., Cruz, A. P., Pitman, N. C. A., Vargas, P. N., Ramirez-Angulo, H., Rudas, A., Salamao, R., Silva, N., Terborgh, J., and Torres-Lezama, A.: Drought sensitivity of the Amazon rainforest, Science, 323, 1344-1347, doi:10.1126/science.1164033, 2009.

Potter, C. S., Randerson, J. T., Field, C. B., Matson, P. A., Vitousek, P. M., Mooney, H. A., and Klooster, S. A.: Terrestrial ecosystem production - a process model-based on global satellite and surface data, Global Biogeochem. Cy., 7, 811-841, doi:10.1029/93gb02725, 1993.

Reichstein, M., Ciais, P., Papale, D., Valentini, R., Running, S., Viovy, N., Cramer, W., Granier, A., Ogee, J., Allard, V., Aubinet, M., Bernhofer, C., Buchmann, N., Carrara, A., Grunwald, T., Heimann, M., Heinesch, B., Knohl, A., Kutsch, W., Loustau, D., Manca, G., Matteucci, G., Miglietta, F., Ourcival, J. M., Pilegaard, K., Pumpanen, J., Rambal, S., Schaphoff, S., Seufert, G., Soussana, J. F., Sanz, M. J., Vesala, T., and Zhao, M.: Reduction of ecosystem productivity and respiration during the European summer 2003 climate anomaly: a joint flux tower, remote sensing and modelling analysis, Global Change Biol., 13, 634-651, doi:10.1111/j.1365-2486.2006.01224.x, 2007a.

Reichstein, M., Papale, D., Valentini, R., Aubinet, M., Bernhofer, C., Knohl, A., Laurila, T., Lindroth, A., Moors, E., Pilegaard, K., and Seufert, G.: Determinants of terrestrial ecosystem carbon balance inferred from European eddy covariance flux sites, Geophys. Res. Lett., 34, L01402, doi:10.1029/2006g1027880, $2007 \mathrm{~b}$.

Rhee, J., Im, J., and Carbone, G. J.: Monitoring agricultural drought for arid and humid regions using multi-sensor remote sensing data, Remote Sens. Environ., 114, 2875-2887, doi:10.1016/j.rse.2010.07.005, 2010.

Samanta, A., Costa, M. H., Nunes, E. L., Vieira, S. A., Xu, L., and Myneni, R. B.: Comment on "Drought-induced reduction in global terrestrial net primary production from 2000 through 2009”, Science, 333, 1093, doi:10.1126/science.1199048, 2011.

Sheffield, J., Wood, E. F., and Roderick, M. L.: Little change in global drought over the past 60 years, Nature, 491, 435-438, doi:10.1038/nature11575, 2012.

Sitch, S., Huntingford, C., Gedney, N., Levy, P. E., Lomas, M., Piao, S. L., Betts, R., Ciais, P., Cox, P., Friedlingstein, P., Jones, C. D., Prentice, I. C., and Woodward, F. I.: Evaluation of the terrestrial carbon cycle, future plant geography and climate-carbon cycle feedbacks using five Dynamic Global Vegetation Models (DGVMs), Global Change Biol., 14, 2015-2039, doi:10.1111/j.1365-2486.2008.01626.x, 2008.

Tucker, C. J., Pinzon, J. E., Brown, M. E., Slayback, D. A., Pak, E. W., Mahoney, R., Vermote, E. F., and El Saleous, N.: An extended AVHRR 8-km NDVI dataset compatible with MODIS and SPOT vegetation NDVI data, Int. J. Remote Sens., 26, 44854498, doi:10.1080/01431160500168686, 2005

van der Molen, M. K., Dolman, A. J., Ciais, P., Eglin, T., Gobron, N., Law, B. E., Meir, P., Peters, W., Phillips, O. L., Reichstein, M., Chen, T., Dekker, S. C., Doubkova, M., Friedl, M. A., Jung, M., van den Hurk, B. J. J. M., de Jeu, R. A. M., Kruijt, B., Ohta, T., Rebel, K. T., Plummer, S., Seneviratne, S. I., Sitch, S., Teuling, A. J., van der Werf, G. R., and Wang, G.: Drought and ecosystem carbon cycling, Agr. Forest Meteorol., 151, 765-773, doi:10.1016/j.agrformet.2011.01.018, 2011.

van der Werf, G. R., Randerson, J. T., Collatz, G. J., Giglio, L., Kasibhatla, P. S., Arellano, A. F., Olsen, S. C., and Kasischke, E. S.: Continental-scale partitioning of fire emissions during the 1997 to 2001 El Niño/La Niña period, Science, 303, 73-76, doi:10.1126/science.1090753, 2004.

van der Werf, G. R., Randerson, J. T., Giglio, L., Collatz, G. J., Mu, M., Kasibhatla, P. S., Morton, D. C., DeFries, R. S., Jin, Y., and van Leeuwen, T. T.: Global fire emissions and the contribution of deforestation, savanna, forest, agricultural, and peat fires (19972009), Atmos. Chem. Phys., 10, 11707-11735, doi:10.5194/acp10-11707-2010, 2010.

Vicente-Serrano, S. M., Begueria, S., and Lopez-Moreno, J. I.: A multiscalar drought index sensitive to global warming: the standardized precipitation evapotranspiration index, J. Climate, 23, 1696-1718, doi:10.1175/2009JCLI2909.1, 2010.

Vicente-Serrano, S. M., Gouveia, C., Camarero, J. J., Begueria, S., Trigo, R., Lopez-Moreno, J. I., Azorin-Molina, C., Pasho, E., Lorenzo-Lacruz, J., Revuelto, J., Moran-Tejeda, E., and SanchezLorenzo, A.: Response of vegetation to drought time-scales 
across global land biomes, P. Natl. Acad. Sci. USA, 110, 52-57, 2013.

Zeng, N., Mariotti, A., and Wetzel, P.: Terrestrial mechanisms of interannual $\mathrm{CO}_{2}$ variability, Global Biogeochem. Cy., 19, GB1016, doi:10.1029/2004GB002273, 2005.

Zhang, Y. C., Rossow, W. B., Lacis, A. A., Oinas, V., and Mishchenko, M. I.: Calculation of radiative fluxes from the surface to top of atmosphere based on ISCCP and other global data sets: Refinements of the radiative transfer model and the input data, J. Geophys. Res-Atmos., 109, D19105, doi:10.1029/2003jd004457, 2004.
Zhao, M. S. and Running, S. W.: Drought-induced reduction in global terrestrial net primary production from 2000 through 2009, Science, 329, 940-943, doi:10.1126/science.1192666, 2010. 